\title{
JARINGAN SYARAF TIRUAN ALGORITMA BACKPROPAGATION DALAM MEMPREDIKSI KETERSEDIAAN KOMODITI PANGAN PROVINSI RIAU
}

\author{
${ }^{1)}$ Eka Pandu Cynthia, ${ }^{2)}$ Edi Ismanto \\ ${ }^{1)}$ UIN Sultan Syarif Kasim Riau, ${ }^{2)}$ Universitas Muhammadiyah Riau \\ ${ }^{1)}$ Jl. HR. Soebrantas KM 15 Pekanbaru, ${ }^{2)}$ Jl. KH. Ahmad Dahlan Pekanbaru \\ E-Mail : eka.pandu.cynthia@uin-suska.ac.id,edi.ismanto@umri.ac.id
}

\begin{abstract}
ABSTRAK
Sebuah sistem untuk prediksi ketersediaan komoditi pangan dapat membantu dalam menentukan keputusan. Jaringan Syaraf Tiruan merupakan metode yang mampu melakukan proses matematis untuk prediksi kertersediaan komoditi pangan. Dengan algoritma Backpropagation, dilakukan proses pengolahan data terdahulu yang dijadikan input untuk prediksi ketersediaan komoditi pangan. Data yang diolah sebagai variabel input adalah Luas Area Panen, Tingkat Produktivitas, Jumlah Produksi dan Jumlah Kebutuhan Konsumsi. Sementara komoditi pangan yang diolah adalah jenis Padi, Jagung, Kedelai, Kacang Tanah, Kacang Hijau, Ubi Kayu dan Ubi Jalar. Data-data tersebut diambil dari tahun 2006 hingga tahun 2013. Tahun 2006 hingga 2012 dijadikan data input, sementara untuk tahun 2013 dijadikan data target. Beberapa tahapan Backpropagation yaitu dengan inisialisasi bobot, aktivasi, menghitung bobot input dan bias output dan perubahan bobot dan bias. Tahapan tersebut akan diperoleh output yang ingin dicapai dengan pendekatan error terkecil sehingga di peroleh hasil prediksi ketersediaan komoditi pangan. Proses pelatihan menggunakan alat bantu perangkat lunak Matlab 6.1. Hasilnya adalah prediksi jumlah ketersediaan komoditi pangan dengan proses pelatihan dan pengujian menghasilkan actual output sebagai target yang dicapai.
\end{abstract}

Kata Kunci : Jaringan Syaraf Tiruan, Backpropagation, Prediksi, Komoditi Pangan.

\begin{abstract}
A prediction system for availability of food commodities that can assist in determining the decision. Artificial neural network is a method that is capable of performing a mathematical process for prediction availability of food commodities. With the backpropagation algorithm, performed data processing is used as input for the previous prediction availability of food commodities. The processed data as input variables is Harvested Area, Productivity Levels, Total Production and Total Consumption Needs. While processed food commodities is kind of Rice, Corn, Soybean, Peanut, Green Beans, Cassava and Sweet Potatoes. The data was taken from 2006 to 2013, 2006 to 2012 used as input data, while for the year 2013 used as target data. Some stages of the backpropagation with weight initialization, activation, calculate the weight of input and output bias, and changes in the weights and biases. Stages will be obtained outputs to be achieved with the smallest error approach so that the obtained results predicted availability of food commodities. The training process using software tools Matlab 6.1. The result is a prediction of the amount of the availability of food commodities with the training and testing process produces the actual output targets are achieved.
\end{abstract}

Keywords : Artificial Neural Network, Backpropagation, Prediction, Food Commodities

\section{PENDAHULUAN}

Sebuah Jaringan Syaraf Tiruan (Artificial Neural Network) adalah sebuah paradigma pengolahan informasi yang terinspirasi dari sistem kerja syaraf biologis, seperti kinerja otak, yang memproses suatu informasi. Elemen kunci dari dari paradigma ini adalah suatu struktur baru dari sistem pengolahan informasi.
Hal ini terdiri dari sejumlah besar elemenelemen pemrosesan yang saling berubungan (neuron) dan saling bekerjasama untuk pemecahan masalah-masalah tertentu (Balaji dan Baskaran, 2013).

Jaringan Syaraf Tiruan, seperti manusia, belajar dari contoh atau pola. Sebuah jaringan syaraf tiruan adalah hasil konfigurasi untuk aplikasi tertentu, seperti pengenalan pola atau klasifikasi data, 
melalui suatu proses pembelajaran. Pembelajaran dalam sistem biologis menambahkan penyesuaian koneksi sinaptik yang ada diantara neuron. Jaringan syaraf tiruan memiliki kemampuan untuk mengekstrak hubungan antara input dan output dari sebuah proses, tanpa adanya keberadaan fisik (Devi et al, 2012).

Backpropagation, atau propagasi error, adalah metode umum dari pembelajaran Jaringan Syaraf Tiruan bagaimana menyelesaikan suatu tugas yang diberikan. Ini merupakan suatu proses pembelajaran terawasi dan merupakan implementasi dari delta rule (Vamsidhar et al, 2010). Hal ini juga menyediakan metode komputasi yang efisien untuk perubahan bobot dalam jaringan umpan maju (feed forward) dengan unit-unit fungsi aktivasi terdiferensial untuk pembelajaran sebuah set pola input output (Rebello et al, 2011).

Jaringan perambatan galat mundur (backpropagation) merupakan salah satu algoritma Jaringan Syaraf Tiruan yang sering digunakan untuk menyelesaikan masalahmasalah yang rumit berkaitan dengan identifikasi, prediksi, pengenalan pola dan sebagainya (Anwar, 2011).

Ketersediaan pangan yang cukup dan merata merupakan salah satu pilar perwujudan ketahanan pangan yang mantap dan berkesinambungan (Undang-Undang No 7 Tahun 1996 tentang pangan, dan penjelasan PP no 68 Tahun 2002). Tersedianya datadata tentang ketahanan pangan merupakan hal yang sangat mendasar untuk digunakan sebagai tolak ukur dalam mengestimasi dan menilai keberhasilan pembangunan ketahanan pangan serta memprediksi situasi ketahanan pangan sebagai isyarat dini untuk upaya perbaikan.
Dari gambaran wacana di atas, penulis akan mencoba mempelajari dan melakukan analisa pengujian menggunakan Jaringan Syaraf Tiruan Algoritma Backpropagation dalam memprediksi ketersediaan komoditi pangan Provinsi Riau.

Tujuan penulisan penelitian ini adalah :

1. Memahami konsep Jaringan Syaraf Tiruan dan proses Algoritma Backpropagation.

2. Menganalisa hal-hal yang berkenaan dengan ketersediaan komoditi pangan.

3. Merancang suatu arsitektur Jaringan Syaraf Tiruan untuk prediksi ketersediaan komoditi pangan.

4. Membangun suatu arsitektur Jaringan Syaraf Tiruan menggunakan Algoritma Backpropagation untuk prediksi ketersediaan komoditi pangan.

5. Melakukan pengujian arsitektur Jaringan Syaraf Tiruan Algoritma Backpropagation dalam memprediksi ketersediaan komoditi pangan.

\section{Kecerdasan Buatan (Artificial \\ Intelligence)}

Kecerdasan Buatan (Artificial Intelligence atau $A I$ ) didefinisikan sebagai kecerdasan yang ditunjukkan oleh suatu entitas buatan. Sistem seperti ini umumnya dianggap komputer. Kecerdasan diciptakan dan dimasukkan ke dalam suatu mesin (komputer) agar dapat melakukan pekerjaan seperti yang dapat dilakukan manusia. Beberapa macam bidang yang menggunakan kecerdasan buatan antara lain sistem pakar, permainan komputer (games), logika fuzzy, jaringan syaraf tiruan dan robotika (Nasution, 2012).

Jaringan Syaraf Tiruan (Artificial Neural Networks) 
Jaringan Syaraf Tiruan adalah merupakan salah satu representasi buatan dari otak manusia yang selalu mencoba untuk mensimulasikan proses pembelajaran pada otak manusia tersebut. Istilah buatan disini digunakan karena jaringan syaraf ini diimplemintasikan dengan menggunakan program komputer yang mampu menyelesaikan sejumlah proses perhitungan selama proses pembelajaran (Andrijasa dan Mistianingsih, 2010).

Pada penelitian ini akan dirancang jaringan syaraf tiruan model lapisan banyak yang mana arsitektur tipe ini memiliki satu atau lebih lapisan yang terletak di antara lapisan masukan dan lapisan keluaran, memiliki juga satu atau lebih lapisan tersembunyi. Umumnya, ada lapisan bobot-bobot yang terletak antara dua lapisan yang bersebelahan. Jaringan dengan banyak lapisan ini dapat menyelesaikan permasalahan yang lebih sulit daripada lapisan dengan lapisan tunggal, tentu saja dengan pembelajaran yang lebih rumit juga. Gambar 1 merupakan salah satu contoh model neuron dengan banyak lapisan dan hanya memiliki satu lapisan tersembunyi. $V_{i j}$ adalah bobot-bobot yang menghubungkan antara neuron-neuron pada lapisan masukan dengan lapisan tersembunyi. Sedangkan $W_{j k}$ adalah bobot-bobot yang menghubungkan antara neuron-neuron pada lapisan tersembunyi dengan lapisan keluaran. $z$ in adalah hasil pengolahan data pada lapisan tersembunyi dengan fungsi aktivasi $F 1$ untuk menghasilkan $z_{j}(j=1, \ldots, k)$;

$$
\begin{aligned}
z_{-} i n_{j} & =\sum_{i=1}^{n} x_{i} \cdot w_{i j} \\
z_{j} & =F 1\left(z_{\text {in }}\right)
\end{aligned}
$$

Sedangkan $y_{\text {_ink }}$ adalah hasil pengolahan data pada lapisan keluaran dengan fungsi aktivasi F2 untuk menghasilkan keluaran jaringan.

$$
\begin{gathered}
y_{k} ;(k=1, \ldots, L) \\
y_{-} i n_{k}=\sum_{j=1}^{n} z_{i} \cdot w_{j k} \\
z_{j}=F 2\left(y_{i n_{k}}\right)
\end{gathered}
$$

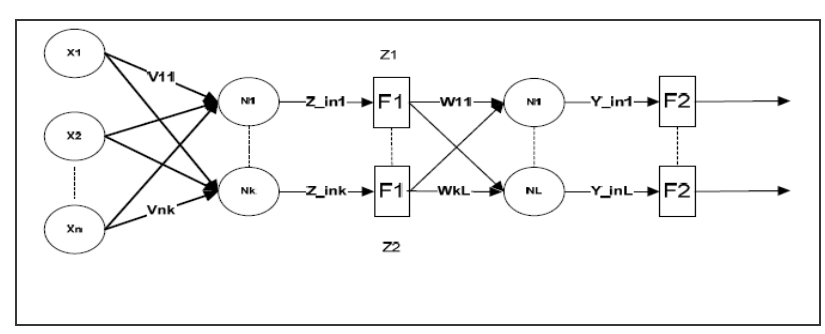

Gambar 1. Model Neuron Dengan Banyak Lapisan

Fungsi aktivasi yang digunakan untuk jaringan syaraf tiruan pada penelitian ini adalah fungsi sigmoid biner. Fungsi ini dilatih menggunakan metode Backpropagation. Fungsi sigmoid biner yang tampak pada Gambar 2 memiliki nilai antara 0 sampai 1 . Karena itu, fungsi ini sering digunakan untuk jaringan syaraf yang membutuhkan nilai keluaran yang terletak pada interval 0 sampai 1. Fungsi sigmoid biner dirumuskan sebagai berikut :

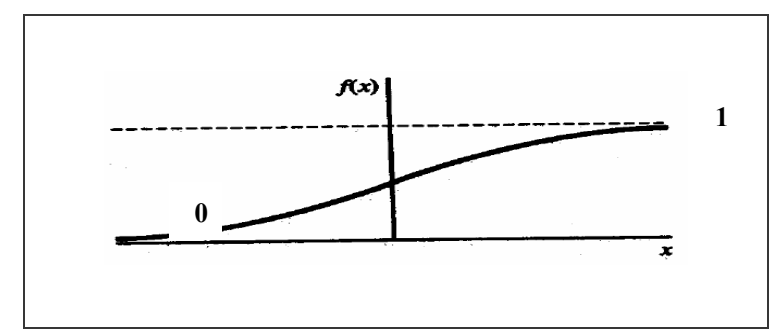

Gambar 2. Fungsi Aktivasi Sigmoid Biner

$$
\begin{gathered}
\mathrm{y}=f(x)=\frac{1}{1+e^{-\sigma x}} \\
y=f(x)=\sigma f(x)[1-f(x)]
\end{gathered}
$$

Untuk menormalisasikan/transformasi data dan nilai agar dapat bernilai 0 hingga 1, dapat menggunakan rumus sebagai berikut (Sya'diyah, 2011) : 


$$
=\frac{\text { Nilai } X_{\text {baru }}}{\text { Nilai } X_{\text {Lama }}-\text { Nilai } X_{\text {Minimum }}}
$$

\section{Algoritma Backpropagation}

Jaringan syaraf tiruan dengan layer tunggal memiliki keterbatasan dalam pengenalan pola. Kelemahan ini bisa ditanggulangi dengan menambahkan satu atau beberapa layer tersembunyi di antara layer masukan dan layer keluaran. Jaringan Syaraf Tiruan Backpropagation (JST-BP) melatih jaringan mendapatkan keseimbangan antara kemampuan jaringan untuk mengenali pola yang digunakan selama pelatihan serta kemampuan untuk memberikan respon yang benar terhadap pola masukan yang serupa dengan pola yang dipakai selama pelatihan (Jumarwanto. et al, 2009).

\section{Pelatihan Algoritma Backpropagation}

Pelatihan Backpropagation dilakukan melalui langkah-langkah berikut ini : (Anike. et al, 2012).

0 . Inisialisasi bobot;

1. Selama kondisi berhenti bernilai salah, kerjakan langkah 2 -9;

2. Untuk setiap data training, lakukan langkah $3-8$.

3. Untuk langkah 3 hingga 5 merupakan Proses Umpan Maju (Feedforward). Setiap unit input $\left(X_{i}, i=1, \ldots, n\right)$; menerima sinyal input dan menyebarkan sinyal tersebut ke seluruh unit tersembunyi.

4. Pada setiap unit tersembunyi $\left(Z_{j}, j=\right.$ $1, \ldots, p)$; menjumlahkan sinyal-sinyal input yang sudah berbobot (termasuk bias nya)

$$
z_{-} i n_{j}=v 0_{j}+\sum_{i=1}^{n} x_{i} \cdot v_{i j}
$$

Lalu menghitung sinyal output dari unit tersembunyi dengan menggunakan fungsi aktivasi yang telah ditentukan $z_{j}=f\left(z_{i n_{j}}\right) . \quad$ Sinyal output ini selanjutnya dikirim ke seluruh unit pada unit diatas (unit output).

5. Tiap-tiap output $\left(Y_{k}, k=1, \ldots, m\right)$; menjumlahkan bobot sinyal input :

$$
y_{-} i n_{k}=w 0_{k}+\sum_{i=1}^{p} z_{i} \cdot w_{j k}
$$

Lalu menghitung sinyal output dari unit output bersangkutan dengan menggunakan fungsi aktivasi yang telah ditentukan $y_{k}=f\left(y_{i n_{k}}\right)$. Sinyal output ini selanjutnya dikirim ke seluruh unit output.

6. Untuk langkah 6 hingga 7 merupakan Proses Umpan Mundur (Backrward) / Propagasi Error. Setiap unit output $\left(Y_{k}\right.$, $k=1, \ldots, m)$; menerima suatu pola target yang sesuai dengan pola input pelatihan, untuk menghitung kesalahan (error) antara target dengan output yang dihasilkan jaringan;

$$
\delta_{k}=\left(t_{k}-y_{y}\right) f^{\prime}\left(y_{i n_{k}}\right)
$$

Faktor $\delta_{k}$ digunakan untuk menghitung koreksi error $\left(\Delta w_{j k}\right)$ yang nantinya akan dipakai untuk memperbaiki $w_{j k}$ dimana :

$$
\Delta w_{j k}=\alpha \delta_{k} z_{j}
$$

Selain itu juga dihitung koreksi bias $\left(\Delta w_{o k}\right)$ yang nantinya akan dipakai untuk memperbaiki $w_{o k}$ dimana :

$$
\Delta w_{o k}=\alpha \delta_{k}
$$

Faktor $\delta_{k}$ kemudian dikirimkan ke lapisan yang berada pada langkah 7 .

7. Setiap unit tersembunyi $\left(Z_{j}, j=1, \ldots, p\right)$; menerima input delta (dari langkah ke6) yang sudah berbobot :

$$
\delta_{\_} i n_{j}=\sum_{k=1}^{m} \delta_{k} w_{j k}
$$


Kemudian hasilnya dikalikan dengan turunan dari fungsi aktivasi yang digunakan untuk menghitung informasi kesalahan error $\delta_{i}$ dimana :

$$
\delta_{j}=\delta_{-} i n_{j} f^{\prime}\left(z_{i n_{j}}\right)
$$

Kemudian hitunglah koreksi bobot dengan :

$$
\Delta v_{i j}=\alpha \delta_{j} x_{i}
$$

Kemudian hitunglah koreksi bias :

$$
\Delta v_{o j}=\alpha \delta_{j}
$$

8. Untuk langkah 6 hingga 7 merupakan Proses Update Bobot dan Bias. Setiap unit output $\left(Y_{k}, \quad k=1, \ldots, \quad m\right)$; memperbaiki bobot dan bias dari seti ap unit tersembunyi $(j=0, \ldots, p)$;

$$
w_{j k}(\text { baru })=w_{j k}(\operatorname{lama})+\Delta w_{j k}
$$

9. Tes kondisi berhenti apabila error ditemukan. Jika kondisi berhenti terpenuhi, maka pelatihan jaringan dapat dihentikan.

\section{Pengujian Backpropagation}

Pengujian dilakukan melalui feedforward dengan langkah-langkah sebagai berikut :

0 . Inisialisasi bobot (hasil pelatihan);

1. Untuk setiap vektor input, kerjakan langkah $2-4$;

2. Untuk $i=1, \ldots, n:$ set aktivasi unit input $X_{1}$.

3. Untuk $j=1, \ldots, p$ :

$$
\begin{aligned}
& z_{-} i n_{j}=v_{o j}+\sum_{i=1}^{n} x_{i} \cdot v_{i j} \\
& z_{j}=f\left(z_{i n_{j}}\right)
\end{aligned}
$$

4. Untuk $k-1, \ldots, p$ :

$$
\begin{gathered}
y_{-} i n_{k}=w_{o k}+\sum_{i=1}^{n} z_{i} \cdot w_{j k} \\
y_{k}=f\left(y_{i n_{k}}\right)
\end{gathered}
$$

Denormalisasi Testing
Setelah dilakukan proses training dan testing pola-pola yang dilatih, maka akan diperoleh hasil bahwa pengujian terhadap pola-pola tersebut apakah telah benar/akurat atau sebaliknya. Untuk menghitung Rata-rata Error (RMSE) jaringan, dapat dilakukan dengan rumus (Andrijasa dan Mistianingsih, 2010) :

$$
R M S E=\sum_{i=1}^{n} \frac{\left(y_{i}-y_{n}\right)^{2}}{N}
$$

Di mana :

$y_{i}=$ Nilai aktual data (target)

$y_{n}=$ Nilai hasil prediksi (actual output)

$N=$ Jumlah data yang diujikan

Sedangkan untuk proses denormalisasi atau mengembalikan kembali nilai hasil prediksi jaringan ke bentuk data semula (sebelum normalisasi) dapat menggunakan rumus sebagai berikut :

$$
x_{i}=y_{n}\left(x_{\max }-x_{\min }\right)+x_{\min }
$$

Di mana :

$x_{i}=$ Nilai $X$ yang akan dilakukan denormalisasi

$y_{n}=$ Nilai hasil prediksi (actual output) yang sesuai dengan $x_{i}$

$x_{\max }=$ Nilai maksimum pada barisan $X$

$x_{\min }=$ Nilai minimum pada barisan $X$

\section{Prediksi / Peramalan}

Teknik peramalan banyak digunakan untuk proses perencanaan dan pengambilan keputusan, suatu ramalan mencoba memperkirakan apa yang akan terjadi dan apa yang akan menjadi kebutuhan. Dalam JST terdapat teknik peramalan yang sering digunakan yaitu backpropagation. Teknik ini biasanya digunakan pada jaringan multilayer dengan tujuan meminimalkan error pada keluaran yang dihasilkan oleh jaringan (Anike. et al, 2012).

Salah satu cara peramalan adalah dengan $\frac{\text { metode urutan waktu (time series) yang }}{\text { Penulis Pertama: Eka Pandu Cyntihia }}$ 
menggunakan data history (data waktu lampau), misalnya data permintaan, untuk membuat ramalan permintaan diwaktu mendatang. Tujuan dari metode ini adalah untuk mengidentifikasi pola data history dan kemudian mengekstrapolasikan pola ini ke masa datang. Metode $N N$ ini dilatih dengan seperangkat data untuk bisa mengenal dan mengidentifikasi pola data atau kurva. Proses pelatihan disebut tahap belajar (Learning Process), yang merupakan bagian penting dalam metode ini. Pemilihan algoritma dan parameter yang bersesuaian dan penentuan berapa banyak perangkat data yang dibutuhkan sangat penting untuk menentukan akurasi dari peramalan yang dihasilkan (Yanti, 2011).

\section{METODE}

\section{Analisis Kebutuhan}

Pada penelitian ini, analisa kebutuhan yang dibutuhkan analisa kebutuhan masukan, kebutuhan proses dan kebutuhan keluaran.

\section{Analisis Kebutuhan Masukan}

Dalam analisa kebutuhan masukan (input) pada penelitian ini dibutuhkan data komoditi pangan yang akan melalui proses pelatihan dan pengujian menggunakan jaringan syaraf tiruan algoritma backpropagation, berikut tabel data komoditi pangan yang akan digunakan.

Tabel 1. Komoditi Pangan Provinsi Riau

\begin{tabular}{|c|c|c|c|c|c|c|c|c|c|c|c|c|c|c|}
\hline \multirow[b]{2}{*}{$\begin{array}{c}\text { Tah } \\
\text { un }\end{array}$} & \multicolumn{7}{|c|}{ Luas Area Panen (Ha) } & \multicolumn{7}{|c|}{ Produktivitas (KuHa) } \\
\hline & Padi & $\begin{array}{l}\text { Jag } \\
\text { ung }\end{array}$ & $\begin{array}{c}\text { Kede } \\
\text { lai }\end{array}$ & $\begin{array}{c}\text { Kac } \\
\text { ang } \\
\text { Tan } \\
\text { ah }\end{array}$ & $\begin{array}{c}\text { Kac } \\
\text { ang } \\
\text { Hija } \\
\text { u }\end{array}$ & $\begin{array}{c}\text { Ubi } \\
\text { Ka } \\
\text { yu }\end{array}$ & $\begin{array}{c}\text { Ubi } \\
\text { Jala } \\
\mathbf{r} \\
\end{array}$ & $\begin{array}{r}\mathbf{P a} \\
\text { di }\end{array}$ & $\begin{array}{l}\text { Jag } \\
\text { ung }\end{array}$ & $\begin{array}{c}\text { Ked } \\
\text { elai }\end{array}$ & $\begin{array}{c}\text { Kac } \\
\text { ang } \\
\text { Tan } \\
\text { ah }\end{array}$ & $\begin{array}{c}\text { Kac } \\
\text { ang } \\
\text { Hija } \\
\text { u }\end{array}$ & $\begin{array}{c}\text { Ubi } \\
\text { Ka } \\
\text { yu }\end{array}$ & $\begin{array}{c}\text { Ubi } \\
\text { Jal } \\
\text { ar }\end{array}$ \\
\hline$F_{1}$ & $F_{2}$ & $F_{3}$ & $F_{4}$ & $F_{5}$ & $F_{6}$ & $\boldsymbol{F}_{7}$ & $F_{8}$ & $F_{9}$ & $F_{10}$ & $F_{11}$ & $F_{12}$ & $F_{13}$ & $F_{14}$ & $F_{15}$ \\
\hline$X_{1}$ & $\begin{array}{c}136 . \\
177\end{array}$ & $\begin{array}{r}15.5 \\
39\end{array}$ & 3.994 & $\begin{array}{r}3.61 \\
9\end{array}$ & $\begin{array}{r}2.19 \\
4\end{array}$ & $\begin{array}{r}4.4 \\
10\end{array}$ & $\begin{array}{r}1.41 \\
3\end{array}$ & $\begin{array}{r}31 \\
53\end{array}$ & $\begin{array}{r}22,3 \\
5\end{array}$ & $\begin{array}{r}10,5 \\
3\end{array}$ & 9,36 & $\begin{array}{r}10,5 \\
3\end{array}$ & $\begin{array}{r}108 \\
00\end{array}$ & $\begin{array}{r}78, \\
72\end{array}$ \\
\hline$X_{2}$ & $\begin{array}{r}147 . \\
167 \\
\end{array}$ & $\begin{array}{r}18.3 \\
79 \\
\end{array}$ & 2.266 & $\begin{array}{r}3.47 \\
5 \\
\end{array}$ & $\begin{array}{r}1.65 \\
0 \\
\end{array}$ & $\begin{array}{r}4.7 \\
18 \\
\end{array}$ & $\begin{array}{r}1.62 \\
7 \\
\end{array}$ & $\begin{array}{r}33, \\
30 \\
\end{array}$ & $\begin{array}{r}21,9 \\
9 \\
\end{array}$ & $\begin{array}{r}10,6 \\
8 \\
\end{array}$ & 9,28 & $\begin{array}{r}10,5 \\
4 \\
\end{array}$ & $\begin{array}{r}109 \\
76 \\
\end{array}$ & $\begin{array}{r}78, \\
76 \\
\end{array}$ \\
\hline$X_{3}$ & $\begin{array}{r}147 . \\
796 \\
\end{array}$ & $\begin{array}{r}21.3 \\
97 \\
\end{array}$ & 4.319 & $\begin{array}{r}2.41 \\
2 \\
\end{array}$ & $\begin{array}{r}1.57 \\
7 \\
\end{array}$ & $\begin{array}{r}4.6 \\
25 \\
\end{array}$ & $\begin{array}{r}1.42 \\
9 \\
\end{array}$ & $\begin{array}{r}33 \\
44 \\
\end{array}$ & $\begin{array}{r}22,4 \\
1 \\
\end{array}$ & $\begin{array}{r}10,8 \\
6 \\
\end{array}$ & 9,29 & $\begin{array}{r}10,7 \\
0 \\
\end{array}$ & $\begin{array}{r}109 \\
78 \\
\end{array}$ & $\begin{array}{r}79, \\
29 \\
\end{array}$ \\
\hline$X_{4}$ & $\begin{array}{r}149 . \\
423 \\
\end{array}$ & $\begin{array}{r}25.0 \\
16 \\
\end{array}$ & 4.906 & $\begin{array}{r}2.02 \\
3 \\
\end{array}$ & 958 & $\begin{array}{r}4.3 \\
79 \\
\end{array}$ & $\begin{array}{r}1.23 \\
0 \\
\end{array}$ & $\begin{array}{r}35, \\
57\end{array}$ & $\begin{array}{r}22,5 \\
9 \\
\end{array}$ & $\begin{array}{r}10,8 \\
0 \\
\end{array}$ & 9,99 & $\begin{array}{r}10,5 \\
8 \\
\end{array}$ & $\begin{array}{r}155, \\
39 \\
\end{array}$ & $\begin{array}{r}79, \\
15 \\
\end{array}$ \\
\hline$X_{5}$ & $\begin{array}{r}156 . \\
088 \\
\end{array}$ & $\begin{array}{r}18.0 \\
44 \\
\end{array}$ & 5.252 & $\begin{array}{r}2.18 \\
8 \\
\end{array}$ & $\begin{array}{r}1.14 \\
0 \\
\end{array}$ & $\begin{array}{r}4.2 \\
37 \\
\end{array}$ & $\begin{array}{r}1.25 \\
2 \\
\end{array}$ & $\begin{array}{r}36, \\
83 \\
\end{array}$ & $\begin{array}{r}23,2 \\
0 \\
\end{array}$ & $\begin{array}{r}11,1 \\
0 \\
\end{array}$ & 9,17 & $\begin{array}{r}10,7 \\
7 \\
\end{array}$ & $\begin{array}{r}179 \\
15 \\
\end{array}$ & $\begin{array}{r}79, \\
61 \\
\end{array}$ \\
\hline$X_{6}$ & $\begin{array}{r}145 . \\
242\end{array}$ & $\begin{array}{r}14.1 \\
39\end{array}$ & 6.425 & $\begin{array}{r}1.81 \\
9 \\
\end{array}$ & 938 & $\begin{array}{r}4.1 \\
44 \\
\end{array}$ & $\begin{array}{r}1.20 \\
3 \\
\end{array}$ & $\begin{array}{r}36, \\
89 \\
\end{array}$ & $\begin{array}{r}23,4 \\
8 \\
\end{array}$ & $\begin{array}{r}11,0 \\
5 \\
\end{array}$ & 9,30 & $\begin{array}{r}10,6 \\
1 \\
\end{array}$ & $\begin{array}{r}191, \\
80 \\
\end{array}$ & $\begin{array}{r}82, \\
39 \\
\end{array}$ \\
\hline$X_{7}$ & $\begin{array}{r}144 . \\
015\end{array}$ & $\begin{array}{r}13.2 \\
84\end{array}$ & 1.949 & $\begin{array}{r}1.72 \\
3\end{array}$ & 865 & $\begin{array}{r}3.6 \\
42\end{array}$ & $\begin{array}{r}1.13 \\
7\end{array}$ & $\begin{array}{c}35 \\
56\end{array}$ & $\begin{array}{r}23,6 \\
6\end{array}$ & $\begin{array}{r}11,3 \\
5\end{array}$ & 9,41 & $\begin{array}{r}10,6 \\
4\end{array}$ & $\begin{array}{r}243 \\
21\end{array}$ & $\begin{array}{r}82, \\
88\end{array}$ \\
\hline$X_{8}$ & $\begin{array}{r}118 . \\
518\end{array}$ & $\begin{array}{r}11.7 \\
48\end{array}$ & 3.686 & $\begin{array}{r}1.32 \\
5\end{array}$ & 585 & $\begin{array}{r}3.8 \\
63\end{array}$ & $\begin{array}{r}1.02 \\
8\end{array}$ & $\begin{array}{r}36 \\
63\end{array}$ & $\begin{array}{r}23,8 \\
8\end{array}$ & $\begin{array}{r}11,3 \\
4\end{array}$ & 9,38 & $\begin{array}{r}10,5 \\
8\end{array}$ & $\begin{array}{r}266, \\
81\end{array}$ & $\begin{array}{r}82, \\
32\end{array}$ \\
\hline
\end{tabular}

\begin{tabular}{|c|c|c|c|c|c|c|c|c|c|c|c|c|c|c|}
\hline \multirow{2}{*}{ Tahun } & \multicolumn{7}{|c|}{ Produksi (Ton) } & \multicolumn{7}{|c|}{ Konsumsi (Ton) } \\
\hline & Padi & Jagung & Kedelai & Kacang & Kacang & Ubi & Ubi & Padi & Jagung & Kedelai & Kacang & Kacang & Ubi & Ubi \\
\hline
\end{tabular}




\begin{tabular}{|c|c|c|c|c|c|c|c|c|c|c|c|c|c|c|}
\hline & & & & Tanah & Hijau & Kayu & Jalar & & & & Tanah & Hijau & Kayu & Jalar \\
\hline$F_{1}$ & $F_{16}$ & $F_{17}$ & $F_{18}$ & $F_{19}$ & $F_{20}$ & $F_{21}$ & $F_{22}$ & $F_{23}$ & $F_{24}$ & $F_{25}$ & $F_{26}$ & $F_{27}$ & $F_{28}$ & $F_{29}$ \\
\hline$X_{I}$ & 429,380 & 34,728 & 4,205 & 3,387 & 2,311 & 47,586 & 11,123 & 546,418 & 11,175 & 42,465 & 4,718 & 4,966 & 26,820 & 9,685 \\
\hline$X_{2}$ & 490,087 & 40,410 & 2,419 & 3,225 & 1,739 & 51,784 & 12,814 & 552,270 & 11,294 & 42,920 & 4,768 & 5,019 & 27,107 & 9,788 \\
\hline$X_{3}$ & 494,260 & 47,959 & 4,689 & 2,240 & 1,688 & 50,772 & 11,330 & 577,028 & 12,194 & 46,287 & 5,137 & 5,396 & 29,214 & 10,533 \\
\hline$X_{4}$ & 531,429 & 56,521 & 5,298 & 2,020 & 1,014 & 68,046 & 9,736 & 557,359 & 11,916 & 45,232 & 5,020 & 5,273 & 28,549 & 10,294 \\
\hline$X_{5}$ & 574,864 & 41,862 & 5,830 & 2,007 & 1,228 & 75,904 & 9,967 & 576,475 & 47,115 & 37,249 & 6,097 & 6,097 & 74,276 & 16,629 \\
\hline$X_{6}$ & 535,788 & 33,197 & 7,100 & 1,692 & 995 & 79,480 & 9,912 & 611,763 & 52,814 & 56,335 & 6,455 & 6,455 & 78,634 & 17,604 \\
\hline$X_{7}$ & 512,152 & 31,433 & 4,182 & 1,622 & 920 & 88,577 & 9,424 & 630,878 & 58,512 & 59,701 & 6,404 & 7,532 & 78,921 & 16,629 \\
\hline$X_{\delta}$ & 434,151 & 28,052 & 2,211 & 1,243 & 619 & 103,070 & 8,462 & 655,637 & 59,411 & 50,663 & 6,762 & 7,225 & 82,991 & 18,109 \\
\hline
\end{tabular}

\section{Analisis Kebutuhan Proses}

Dalam analisa kebutuhan proses pada penelitian ini dibutuhkan perangkat keras dan perangkat lunak melakukan proses pelatihan dan pengujian jaringan syaraf tiruan algoritma backpropagation, berikut perangkat keras dan perangkat lunak yang akan digunakan.

a. Perangkat Keras : Laptop Axioo Pico 10 Inches

Processor : Intel Atom CPU

D2500 1,86 GHz

$\begin{array}{ll}\text { RAM } & : 2 \mathrm{~GB} \\ \text { Harddisk } & : 320 \mathrm{~GB}\end{array}$

b. Perangkat Lunak

Oprating System : Windows 7

Ultimate

Aplikasi Pengujian: Matlab Versi 6.1

\section{Analisis Kebutuhan Keluaran}

Dalam analisa kebutuhan keluaran pada penelitian ini dibutuhkan proses denormalisasi data hasil keluaran dari proses pelatihan dan pengujian. Proses denormalisasi ini dimaksudkan agar datadata dapat dibaca dengan mudah kembali. Selain itu juga dibutuhkan beberapa arsitektur jaringan lain sebagai pembanding atas jaringan yang telah dilatih dan diuji sebelumnya, dan memperoleh arsitektur jaringan terbaik dalam memprediksi ketersediaan komoditi pangan ini.

\section{Kerangka Penelitian}

Kerangka kerja merupakan langkahlangkah dan metode dalam melakukan penelitian. Suatu penelitian biasanya selalu dimulai dengan suatu perencanaan yang seksama yang mengikuti sejumlah petunjuk yang disusun secara sistematis sehingga hasilnya dapat mewakili kondisi yang sebenarnya dan dapat dipertanggung jawabkan. Tahapan dari penelitian ini dapat dilihat pada gambar 3 .

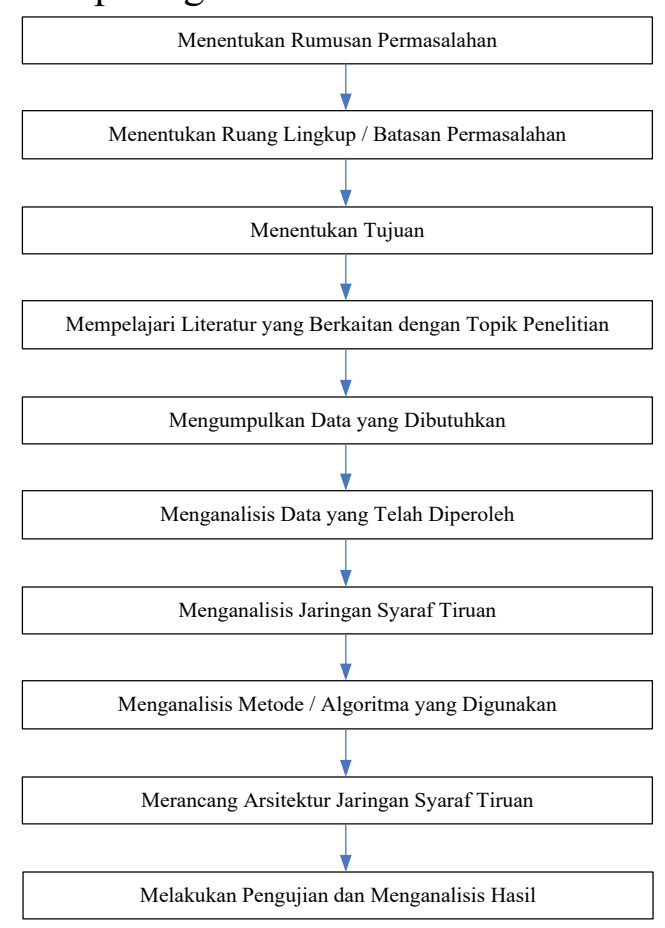

Gambar 3. Tahapan Penelitian 
HASIL

\section{Normalisasi Data}

Data-data yang terdapat pada tabel 4.1 hingga 4.5 tidak dapat kita gunakan secara langsung pada proses pelatihan dan pengujian arsitektur Jaringan Syaraf Tiruan yang kita buat, data-data tersebut nilai nya harus kita normalisasikan terlebih dahulu. Pada penelitian ini menggunakan fungsi aktivasi Sigmoid
Biner, maka nilai-nilai yang akan kita gunakan pada Jaringan Syaraf Tiruan nantinya harus bernilai antara 0 hingga 1 , rumus normalisasi nilai sesuai dengan Rumus 8. Dengan catatan, rujukan nilai untuk menentukan nilai maximum dan minimum adalah perkolom (masing-masing $F$ ) dan sesuaikan dengan jenis tabelnya, karena setiap jenis tabel memiliki satuan yang berbeda-beda.

Tabel 2. Normalisasi Data Komoditi Pangan

\begin{tabular}{|c|c|c|c|c|c|c|c|c|c|c|c|c|c|c|}
\hline$F$ & $F_{2}$ & $F_{3}$ & $F_{4}$ & $F_{5}$ & $F_{6}$ & $\boldsymbol{F}_{7}$ & $F_{8}$ & $F_{9}$ & $F_{10}$ & $F_{11}$ & $F_{12}$ & $F_{13}$ & $F_{14}$ & $F_{15}$ \\
\hline $\begin{array}{c}X \\
1\end{array}$ & $\begin{array}{c}0,47 \\
00\end{array}$ & $\begin{array}{c}0,28 \\
57\end{array}$ & $\begin{array}{c}0,45 \\
69\end{array}$ & $\begin{array}{c}1,00 \\
00\end{array}$ & $\begin{array}{c}1,00 \\
00\end{array}$ & $\begin{array}{c}0,71 \\
38\end{array}$ & $\begin{array}{c}0,64 \\
27\end{array}$ & 0 & $\begin{array}{c}0,19 \\
05\end{array}$ & 0 & $\begin{array}{c}0,23 \\
17\end{array}$ & 0 & 0 & 0 \\
\hline $\begin{array}{l}X \\
2\end{array}$ & $\begin{array}{c}0,76 \\
25\end{array}$ & $\begin{array}{c}0,49 \\
98\end{array}$ & $\begin{array}{c}0,07 \\
08\end{array}$ & $\begin{array}{c}0,93 \\
72\end{array}$ & $\begin{array}{c}0,66 \\
19\end{array}$ & $\begin{array}{c}1,00 \\
00\end{array}$ & $\begin{array}{c}1,00 \\
00\end{array}$ & $\begin{array}{c}0,33 \\
02\end{array}$ & 0 & $\begin{array}{c}0,18 \\
29\end{array}$ & $\begin{array}{c}0,13 \\
41\end{array}$ & $\begin{array}{c}0,0 \\
417\end{array}$ & $\begin{array}{l}0,0 \\
111\end{array}$ & $\begin{array}{c}0,0 \\
096\end{array}$ \\
\hline $\begin{array}{c}X \\
3\end{array}$ & $\begin{array}{c}0,77 \\
93\end{array}$ & $\begin{array}{c}0,72 \\
72\end{array}$ & $\begin{array}{c}0,52 \\
95\end{array}$ & $\begin{array}{c}0,47 \\
38\end{array}$ & $\begin{array}{c}0,61 \\
65\end{array}$ & $\begin{array}{c}0,91 \\
36\end{array}$ & $\begin{array}{c}0,66 \\
94\end{array}$ & $\begin{array}{c}0,35 \\
63\end{array}$ & $\begin{array}{c}0,22 \\
22\end{array}$ & $\begin{array}{c}0,40 \\
24\end{array}$ & $\begin{array}{c}0,14 \\
63\end{array}$ & $\begin{array}{c}0,7 \\
083\end{array}$ & $\begin{array}{l}0,0 \\
112\end{array}$ & $\begin{array}{c}0,1 \\
370\end{array}$ \\
\hline $\begin{array}{l}X \\
4\end{array}$ & $\begin{array}{c}0,82 \\
26\end{array}$ & $\begin{array}{c}1,00 \\
00\end{array}$ & $\begin{array}{c}0,66 \\
06\end{array}$ & $\begin{array}{c}0,30 \\
43\end{array}$ & $\begin{array}{c}0,23 \\
18\end{array}$ & $\begin{array}{c}0,68 \\
49\end{array}$ & $\begin{array}{c}0,33 \\
72\end{array}$ & $\begin{array}{c}0,75 \\
37\end{array}$ & $\begin{array}{c}0,31 \\
75\end{array}$ & $\begin{array}{c}0,32 \\
93\end{array}$ & $\begin{array}{c}1,00 \\
00 \\
\end{array}$ & $\begin{array}{c}0,2 \\
083 \\
\end{array}$ & $\begin{array}{r}0,2 \\
984 \\
\end{array}$ & $\begin{array}{c}0,1 \\
034 \\
\end{array}$ \\
\hline$X$ & $\begin{array}{c}1,00 \\
00\end{array}$ & $\begin{array}{c}0,47 \\
45\end{array}$ & $\begin{array}{c}0,73 \\
79\end{array}$ & $\begin{array}{c}0,37 \\
62\end{array}$ & $\begin{array}{c}0,34 \\
49\end{array}$ & $\begin{array}{c}0,55 \\
30\end{array}$ & $\begin{array}{c}0,37 \\
40\end{array}$ & $\begin{array}{c}0,98 \\
88\end{array}$ & $\begin{array}{c}0,64 \\
02\end{array}$ & $\begin{array}{c}0,69 \\
51\end{array}$ & 0 & $\begin{array}{c}1,0 \\
000\end{array}$ & $\begin{array}{l}0,4 \\
480\end{array}$ & $\begin{array}{c}0,2 \\
139\end{array}$ \\
\hline$X$ & $\begin{array}{c}0,71 \\
13\end{array}$ & $\begin{array}{c}0,18 \\
02\end{array}$ & $\begin{array}{c}1,00 \\
00\end{array}$ & $\begin{array}{c}0,21 \\
53\end{array}$ & $\begin{array}{c}0,21 \\
94\end{array}$ & $\begin{array}{c}0,46 \\
65\end{array}$ & $\begin{array}{c}0,29 \\
22\end{array}$ & $\begin{array}{c}1,00 \\
00\end{array}$ & $\begin{array}{c}0,78 \\
84\end{array}$ & $\begin{array}{c}0,63 \\
41\end{array}$ & $\begin{array}{c}0,15 \\
85\end{array}$ & $\begin{array}{c}0,3 \\
333\end{array}$ & $\begin{array}{c}0,5 \\
277\end{array}$ & $\begin{array}{r}0,8 \\
822\end{array}$ \\
\hline$X$ & $\begin{array}{c}0,67 \\
87\end{array}$ & $\begin{array}{c}0,11 \\
58\end{array}$ & 0 & $\begin{array}{c}0,17 \\
35\end{array}$ & $\begin{array}{c}0,17 \\
40\end{array}$ & 0 & $\begin{array}{c}0,18 \\
20\end{array}$ & $\begin{array}{c}0,75 \\
19\end{array}$ & $\begin{array}{c}0,88 \\
36\end{array}$ & $\begin{array}{c}1,00 \\
00\end{array}$ & $\begin{array}{c}0,29 \\
27\end{array}$ & $\begin{array}{c}0,4 \\
583\end{array}$ & $\begin{array}{l}0,8 \\
514\end{array}$ & $\begin{array}{c}1,0 \\
000\end{array}$ \\
\hline $\bar{X}$ & 0 & 0 & $\begin{array}{c}0,38 \\
81\end{array}$ & 0 & 0 & $\begin{array}{c}0,20 \\
54\end{array}$ & 0 & $\begin{array}{c}0,95 \\
15\end{array}$ & $\begin{array}{c}1,00 \\
00\end{array}$ & $\begin{array}{c}0,98 \\
78\end{array}$ & $\begin{array}{c}0,25 \\
61\end{array}$ & $\begin{array}{c}0,2 \\
083\end{array}$ & $\begin{array}{c}1,0 \\
000\end{array}$ & $\begin{array}{c}0,8 \\
654\end{array}$ \\
\hline
\end{tabular}

\begin{tabular}{|c|c|c|c|c|c|c|c|c|c|c|c|c|c|}
\hline$F_{16}$ & $F_{17}$ & $F_{18}$ & $F_{19}$ & $F_{20}$ & $F_{21}$ & $F_{22}$ & $F_{23}$ & $F_{24}$ & $F_{25}$ & $F_{26}$ & $\boldsymbol{F}_{27}$ & $F_{28}$ & $F_{29}$ \\
\hline 0 & $\begin{array}{l}0,2 \\
345\end{array}$ & $\begin{array}{c}0,40 \\
79\end{array}$ & $\begin{array}{c}1,0 \\
000\end{array}$ & $\begin{array}{c}0,0 \\
013\end{array}$ & 0 & $\begin{array}{c}0,6 \\
114\end{array}$ & 0 & 0 & $\begin{array}{c}0,23 \\
23\end{array}$ & 0 & 0 & 0 & 0 \\
\hline 0,4 & 0,4 & 0,04 & 0,9 & 0,0 & 0,07 & 1,0 & 0,05 & 0,0 & 0,25 & 0,0 & 0,0 & 0,00 & 0,0 \\
\hline 173 & 341 & 25 & 244 & 007 & 57 & 000 & 36 & 025 & 26 & 245 & 207 & 51 & 122 \\
\hline 0,4 & 0,6 & 0,50 & 0,4 & 0,0 & 0,05 & 0,6 & 0,28 & 0,0 & 0,40 & 0,2 & 0,1 & 0,04 & 0,1 \\
\hline 460 & 993 & 69 & 650 & 007 & 74 & 590 & 03 & 211 & 25 & 050 & 676 & 26 & 007 \\
\hline 0,7 & 1,0 & 0,63 & 0,3 & & 0,36 & 0,2 & 0,10 & 0,0 & 0,35 & 0,1 & 0,1 & 0,03 & 0,0 \\
\hline 014 & 000 & 14 & 624 & 0 & 88 & 927 & 02 & 154 & 56 & 477 & 196 & 08 & 723 \\
\hline 1,0 & 0,4 & 0,74 & 0,3 & 0,0 & 0,51 & 0,3 & 0,27 & 0,7 & 0 & 0,6 & 0,4 & 0,84 & 0,8 \\
\hline 000 & 851 & 02 & 563 & 002 & 04 & 458 & 52 & 451 & 0 & 747 & 408 & 48 & 243 \\
\hline 0,7 & 0,1 & 1,00 & 0,2 & 1,0 & 0,57 & 0,3 & 0,59 & 0,8 & 0,85 & 0,8 & 0,5 & 0,92 & 0,9 \\
\hline 314 & 807 & 00 & 094 & 000 & 48 & 332 & 83 & 632 & 01 & 498 & 803 & 24 & 401 \\
\hline
\end{tabular}




\begin{tabular}{cccccccccccccc}
0,5 & 0,1 & 0,40 & 0,1 & 0,9 & 0,73 & 0,2 & 0,77 & 0,9 & 1,00 & 0,8 & 1,0 & 0,92 & 0,8 \\
689 & 188 & 31 & 768 & 245 & 88 & 210 & 33 & 814 & 00 & 249 & 000 & 75 & 243 \\
\hline 0,0 & \multirow{2}{*}{0} & \multirow{2}{*}{0} & 0 & 0,6 & 1,00 & \multirow{2}{*}{0} & 1,00 & 1,0 & 0,59 & 1,0 & 0,8 & 1,00 & 1,0 \\
328 & & & & 217 & 00 & & 00 & 000 & 75 & 000 & 804 & 00 & 000 \\
\hline
\end{tabular}

Arsitektur Jaringan Syaraf Tiruan Yang Akan Dibangun

Pada penelitian ini, akan dirancang suatu arsitektur Jaringan Syaraf Tiruan sebagai berikut :

1. Arsitektur Jaringan Syaraf Tiruan yang dirancang adalah model dengan lapisan banyak.

2. Fungsi aktivasi.

Karakteristik yang harus dimiliki oleh suatu fungsi aktivasi yaitu kontinu, differensiabel dan monoton menurun. Salah satu fungsi yang sering digunakan adalah fungsi sigmoid biner yang memiliki range (0-1). Node pada output layer memiliki nilai antara $0-1$.
3. Input-an parameter jaringan node pada penelitian ini adalah:

Jumlah node input layer $=7$ node, yang telah diinisialisasikan

sebagai $X_{1} \quad$ (Tahun 2006), $X_{2}$

(Tahun 2007), $X_{3}$

(Tahun 2008), $X_{4}$ (Tahun

2009), $X_{5} \quad$ (Tahun 2010), $X_{6}$

(Tahun 2011), $X_{7}$

(Tahun 2012).

Data yang telah dinormalisasi pada Tabel 2 diatas akan ditransformasikan (normalisasikan) kembali dengan melakukan perubahan kolom untuk data node input layer $\left(\mathrm{X}_{1}\right.$ hingga $\left.\mathrm{X}_{7}\right)$ dan $\mathrm{X}_{8}$ sebagai data target.

Tabel 3. Normalisasi Data Input

\begin{tabular}{|c|c|c|c|c|c|c|c|c|}
\hline & $x_{2}$ & $x_{z}$ & $x_{2}$ & $x_{8}$ & $x_{1}$ & $x_{6}$ & $x_{z}$ & $x_{s(s)}$ \\
\hline$F_{1}$ & 0 & 0.1429 & 0.2857 & 0.4286 & 0.5714 & 0.7143 & 0.8571 & 1 \\
\hline$F_{2}$ & 0.4700 & 0.7625 & 0.7793 & 0.8226 & 1 & 0.7113 & 0.6787 & 0 \\
\hline$F_{x}$ & 0.2857 & 0.4998 & 0.7272 & 1 & 0.4745 & 0.1802 & 0.1158 & 0 \\
\hline$F_{e}$ & 0.4569 & 0.0708 & 0.5295 & 0.5605 & 0.7379 & 1 & 0 & 0.3881 \\
\hline$F_{x}$ & 1 & 0.9372 & 0.4738 & 0.3043 & 0.3762 & 0.2153 & 0.1735 & 0 \\
\hline$F_{e}$ & 1 & 0.6619 & 0.6165 & $0.231 \mathrm{~s}$ & 0.3449 & 0.2194 & 0.1740 & 0 \\
\hline$F_{z}$ & 0.7138 & 1 & 0.9136 & 0.6849 & 0.5530 & 0.4665 & 0 & 0.2054 \\
\hline$F_{z}$ & 0.6427 & 1 & 0.6694 & 0.3372 & 0.3740 & 0.2922 & 0.1820 & 0 \\
\hline$F_{8}$ & 0 & 0.3302 & 0.3563 & 0.7537 & 0.9888 & 1 & 0.7519 & 0.9515 \\
\hline$F_{x s}$ & 0.1905 & 0 & 0.2222 & 0.3175 & 0.5402 & 0.7884 & 0.8836 & 1 \\
\hline$F_{z z}$ & 0 & 0.1829 & 0.4024 & 0.3293 & 0.6951 & 0.6341 & 1 & 0.9878 \\
\hline$F_{z z}$ & 0.2317 & 0.1341 & 0.1463 & 1 & 0 & 0.1585 & 0.2927 & 0.2561 \\
\hline$F_{z z}$ & 0 & 0.0417 & 0.7083 & 0.2083 & 1 & 0.3333 & 0.4583 & 0.2083 \\
\hline$F_{21}$ & 0 & 0.0111 & 0.0112 & 0.2984 & 0.4480 & 0.5277 & 0.8514 & 1 \\
\hline$F_{z s}$ & 0 & 0.0095 & 0.1370 & 0.1034 & 0.2139 & 0.3822 & 1 & 0.8654 \\
\hline$F_{z 6}$ & 0 & 0.4173 & 0.4460 & 0.7014 & 1 & 0.7314 & 0.5689 & 0.0328 \\
\hline$F_{z y}$ & 0.2345 & 0.4341 & 0.6993 & 1 & 0.4851 & 0.1807 & $0.118 \mathrm{~s}$ & 0 \\
\hline$F_{z s}$ & 0.4079 & 0.0425 & 0.5069 & 0.6314 & 0.7402 & 1 & 0.4031 & 0 \\
\hline$F_{z y}$ & 1 & 0.9244 & 0.4650 & 0.3624 & 0.3563 & 0.2094 & 0.1768 & 0 \\
\hline$F_{23}$ & 0.0013 & 0.0007 & 0.0007 & 0 & 0.0002 & 1 & 0.9245 & 0.6217 \\
\hline$F_{2 z}$ & 0 & 0.0757 & 0.0574 & $0.368 \mathrm{~B}$ & 0.5104 & 0.5748 & $0.738 \mathrm{~B}$ & 1 \\
\hline$F_{22}$ & 0.6114 & 1 & 0.6550 & 0.2927 & 0.3458 & 0.3332 & 0.2210 & 0 \\
\hline$F_{2 z}$ & 0 & 0.0536 & 0.2803 & 0.1002 & 0.2752 & 0.5983 & 0.7733 & 1 \\
\hline$F_{20}$ & 0 & 0.0025 & 0.0211 & 0.0154 & 0.7451 & 0.8632 & 0.9814 & 1 \\
\hline$F_{2 s}$ & 0.2323 & 0.2526 & 0.4025 & 0.3556 & 0 & 0.8501 & 1 & 0.5975 \\
\hline$F_{28}$ & 0 & 0.0245 & 0.2050 & 0.1477 & 0.6747 & 0.8498 & 0.8249 & 1 \\
\hline$F_{2 y}$ & 0 & 0.0207 & 0.1676 & 0.1196 & 0.4408 & 0.5803 & 1 & 0.8804 \\
\hline$F_{23}$ & 0 & 0.0051 & 0.0426 & 0.0308 & 0.8448 & 0.9224 & 0.9275 & 1 \\
\hline$F_{2 x}$ & 0 & 0.0122 & 0.1007 & 0.0723 & 0.8243 & 0.9401 & 0.8243 & 1 \\
\hline
\end{tabular}


4. Arsitektur Jaringan Syaraf Tiruan menggunakan Algoritma Backpropagation yang dibangun pada penelitian ini dapat dilihat pada Gambar 4.

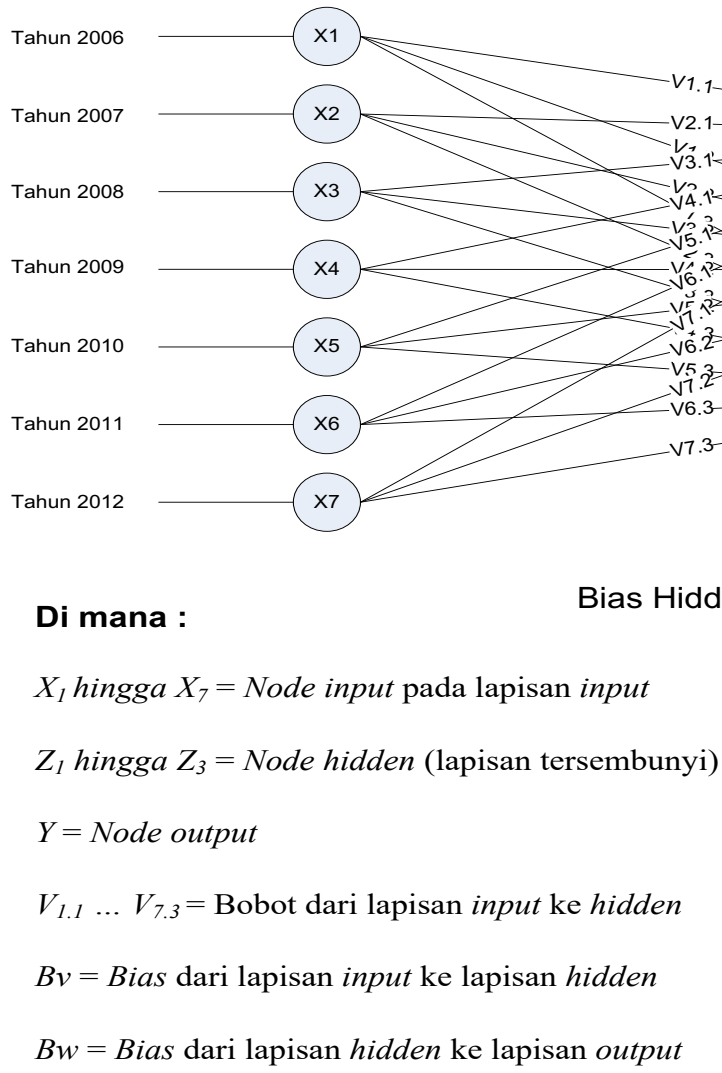

Gambar 4. Arsitektur Jaringan Syaraf Tiruan yang Akan Dibangun

\section{Implementasi dan Pengujian}

Implementasi dan pengujian dari jaringan syaraf tiruan dengan algoritma backpropagation dimulai dengan menjelaskan perangkat lunak pengujian yaitu Matlab, pemrograman jaringan syaraf tiruan, langkah

pengolahan data dengan matlab dan pelatihan jaringan syaraf tiruan.

\section{Implementasi Matlab}

Untuk mengolah data training dan testing dengan menggunakan algoritma bacpropagation di Matlab menggunakan tahapan-tahapan perintah sebagai berikut :
1. Membuat jaringan backpropagation dengan perintah :

net $=n e w f f(\operatorname{minmax}(p),[3,1]$, \{'logsig', 'logsig'\}, 'traingdx');

2. Melihat bobot dari input layer ke hidden layer dengan perintah : net.IW $\{1,1\}$

3. Melihat bobot dari hidden layer ke output layer dengan perintah : net. $L W\{2,1\}$

4. Melihat bias dari input ke hidden layer dengan perintah ; net. $b\{1\}$

5. Melihat bias dari hidden layer ke output layer dengan perintah : net. $b\{2\}$ 
6. Melihat output yang dihasilkan jaringan, error dan performance dengan perintah

\section{[y,Pf,Af,e,perf]}

7. Melakukan training terhadap jaringan syaraf tiruan dengan perintah :

$n e t=\operatorname{train}(n e t, p, t)$

\section{Pengujian}

Dari beberapa pengujian arsitektur model Jaringan Syaraf Tiruan yang telah dilakukan dengan memasukkan parameterparameter berbeda untuk learning rate, goal dan jumlah data, secara keseluruhan dapat dilihat pada Tabel 4 berikut

Tabel 4. Pengujian Arsitektur Model Jaringan Syaraf Tiruan

\begin{tabular}{|c|c|c|c|c|c|c|c|c|c|c|c|}
\hline \multirow[b]{2}{*}{$\begin{array}{l}\mathbf{N} \\
\mathbf{0}\end{array}$} & \multirow[b]{2}{*}{$\begin{array}{c}\text { Arsitekt } \\
\text { ur }\end{array}$} & \multirow{2}{*}{$\begin{array}{c}\text { Jumla } \\
\text { h } \\
\text { Data }\end{array}$} & \multicolumn{3}{|c|}{ Parameter } & \multirow{2}{*}{$\begin{array}{l}\text { Epoch } \\
\text { Ditemuk } \\
\quad \text { an }\end{array}$} & \multicolumn{2}{|c|}{ Output } & \multirow[b]{2}{*}{ RMSE } & \multirow[b]{2}{*}{$\begin{array}{c}\% \\
\text { Akura } \\
\text { si }\end{array}$} & \multirow[b]{2}{*}{ Perf. } \\
\hline & & & LR & $\begin{array}{c}\text { Maks. } \\
\text { Epoc } \\
\text { hs }\end{array}$ & $\begin{array}{c}\text { Goa } \\
\text { I/ } \\
\text { MS } \\
\text { E }\end{array}$ & & $\begin{array}{c}\text { Targ } \\
\text { et }\end{array}$ & Yn & & & \\
\hline
\end{tabular}

\begin{tabular}{|c|c|c|c|c|c|c|c|c|c|c|c|}
\hline \multirow{3}{*}{1} & $\begin{array}{c}\text { Pola 7-3- } \\
1 \\
\end{array}$ & 10 & $\begin{array}{c}0.0 \\
1\end{array}$ & $\begin{array}{c}100.0 \\
00\end{array}$ & 0.01 & 206 & $\begin{array}{c}0.857 \\
1 \\
\end{array}$ & $\begin{array}{c}0.926 \\
9\end{array}$ & $\begin{array}{c}0.00780367 \\
27 \\
\end{array}$ & 99.97 & $\begin{array}{c}0.156 \\
5\end{array}$ \\
\hline & $\begin{array}{c}\text { Pola 7-3- } \\
1\end{array}$ & 20 & $\begin{array}{c}0.0 \\
2\end{array}$ & $\begin{array}{c}100.0 \\
00\end{array}$ & 0.02 & 164 & $\begin{array}{c}0.857 \\
1 \\
\end{array}$ & $\begin{array}{c}0.926 \\
9 \\
\end{array}$ & $\begin{array}{c}0.00977989 \\
60 \\
\end{array}$ & 99.97 & $\begin{array}{c}0.234 \\
8 \\
\end{array}$ \\
\hline & $\begin{array}{c}\text { Pola 7-3- } \\
1\end{array}$ & 29 & $\begin{array}{c}0.0 \\
3\end{array}$ & $\begin{array}{c}100.0 \\
00\end{array}$ & 0.03 & 133 & $\begin{array}{c}0.857 \\
1\end{array}$ & $\begin{array}{c}0.926 \\
9\end{array}$ & $\begin{array}{c}0.01030211 \\
97\end{array}$ & 99.96 & $\begin{array}{c}0.179 \\
9\end{array}$ \\
\hline \multirow{3}{*}{2} & $\begin{array}{c}\text { Pola 7-7- } \\
1 \\
\end{array}$ & 10 & $\begin{array}{c}0.0 \\
1 \\
\end{array}$ & $\begin{array}{c}100.0 \\
00\end{array}$ & 0.01 & 245 & $\begin{array}{c}0.857 \\
1 \\
\end{array}$ & $\begin{array}{c}0.596 \\
6 \\
\end{array}$ & $\begin{array}{c}0.00463325 \\
82 \\
\end{array}$ & 99.98 & $\begin{array}{c}0.206 \\
0\end{array}$ \\
\hline & $\begin{array}{c}\text { Pola 7-7- } \\
1 \\
\end{array}$ & 20 & $\begin{array}{c}0.0 \\
2\end{array}$ & $\begin{array}{c}100.0 \\
00\end{array}$ & 0.02 & 128 & $\begin{array}{c}0.857 \\
1 \\
\end{array}$ & $\begin{array}{c}0.596 \\
6 \\
\end{array}$ & $\begin{array}{c}0.00472085 \\
36 \\
\end{array}$ & 99.98 & $\begin{array}{c}0.167 \\
5\end{array}$ \\
\hline & $\begin{array}{c}\text { Pola 7-7- } \\
1\end{array}$ & 29 & $\begin{array}{c}0.0 \\
3 \\
\end{array}$ & $\begin{array}{c}100.0 \\
00\end{array}$ & 0.03 & 101 & $\begin{array}{c}0.857 \\
1 \\
\end{array}$ & $\begin{array}{c}0.596 \\
6 \\
\end{array}$ & $\begin{array}{c}0.00540061 \\
66 \\
\end{array}$ & 99.98 & $\begin{array}{c}0.201 \\
3 \\
\end{array}$ \\
\hline
\end{tabular}

\begin{tabular}{|c|c|c|c|c|c|c|c|c|c|c|c|}
\hline \multirow{3}{*}{3} & $\begin{array}{c}\text { Pola 7- } \\
14-1\end{array}$ & 10 & $\begin{array}{c}0.0 \\
1\end{array}$ & $\begin{array}{c}100.0 \\
00\end{array}$ & 0.01 & 274 & $\begin{array}{c}0.857 \\
1\end{array}$ & $\begin{array}{c}0.875 \\
8\end{array}$ & $\begin{array}{c}0.00378590 \\
20\end{array}$ & 99.99 & $\begin{array}{c}0.233 \\
5\end{array}$ \\
\hline & $\begin{array}{c}\text { Pola 7- } \\
14-1\end{array}$ & 20 & $\begin{array}{c}0.0 \\
2\end{array}$ & $\begin{array}{c}100.0 \\
00\end{array}$ & 0.02 & 157 & $\begin{array}{c}0.857 \\
1\end{array}$ & $\begin{array}{c}0.875 \\
8\end{array}$ & $\begin{array}{c}0.00433148 \\
66\end{array}$ & 99.99 & $\begin{array}{c}0.277 \\
6\end{array}$ \\
\hline & $\begin{array}{c}\text { Pola 7- } \\
14-1\end{array}$ & 29 & $\begin{array}{c}0.0 \\
3\end{array}$ & $\begin{array}{c}100.0 \\
00\end{array}$ & 0.03 & 110 & $\begin{array}{c}0.857 \\
1\end{array}$ & $\begin{array}{c}0.875 \\
8\end{array}$ & $\begin{array}{c}0.00334382 \\
08\end{array}$ & 99.99 & $\begin{array}{c}0.218 \\
5\end{array}$ \\
\hline
\end{tabular}

\begin{tabular}{|c|c|c|c|c|c|c|c|c|c|c|c|}
\hline \multirow{3}{*}{4} & $\begin{array}{l}\text { Pola 7- } \\
25-1\end{array}$ & 10 & $\begin{array}{c}0.0 \\
1\end{array}$ & $\begin{array}{c}100.0 \\
00\end{array}$ & 0.01 & 125 & $\begin{array}{c}0.857 \\
1\end{array}$ & $\begin{array}{c}0.053 \\
8\end{array}$ & $\begin{array}{c}0.00869972 \\
68\end{array}$ & 99.97 & $\begin{array}{c}0.247 \\
4\end{array}$ \\
\hline & $\begin{array}{l}\text { Pola 7- } \\
25-1\end{array}$ & 20 & $\begin{array}{c}0.0 \\
2\end{array}$ & $\begin{array}{c}100.0 \\
00\end{array}$ & 0.02 & 131 & $\begin{array}{c}0.857 \\
1\end{array}$ & $\begin{array}{c}0.053 \\
8\end{array}$ & $\begin{array}{c}0.01035440 \\
67\end{array}$ & 99.96 & $\begin{array}{c}0.285 \\
3\end{array}$ \\
\hline & $\begin{array}{l}\text { Pola 7- } \\
25-1\end{array}$ & 29 & $\begin{array}{c}0.0 \\
3\end{array}$ & $\begin{array}{c}100.0 \\
00\end{array}$ & 0.03 & 90 & $\begin{array}{c}0.857 \\
1\end{array}$ & $\begin{array}{c}0.053 \\
8\end{array}$ & $\begin{array}{c}0.01327183 \\
81\end{array}$ & 99.95 & $\begin{array}{c}0.400 \\
8\end{array}$ \\
\hline
\end{tabular}

\begin{tabular}{cccccccccccc}
\hline & Pola 7- & \multirow{2}{*}{10} & $\begin{array}{c}0.0 \\
29-1\end{array}$ & $\begin{array}{c}100.0 \\
00\end{array}$ & 0.01 & 159 & $\begin{array}{c}0.857 \\
1\end{array}$ & $\begin{array}{c}0.931 \\
4\end{array}$ & $\begin{array}{c}0.01287961 \\
92\end{array}$ & 99.96 & $\begin{array}{c}0.518 \\
3\end{array}$ \\
\cline { 2 - 10 } 5 & $\begin{array}{c}\text { Pola 7- } \\
29-1\end{array}$ & 20 & $\begin{array}{c}0.0 \\
2\end{array}$ & $\begin{array}{c}100.0 \\
00\end{array}$ & 0.02 & 112 & $\begin{array}{c}0.857 \\
1\end{array}$ & $\begin{array}{c}0.931 \\
4\end{array}$ & $\begin{array}{c}0.01013708 \\
75\end{array}$ & $\begin{array}{c}99.97 \\
0.453 \\
6\end{array}$ \\
\cline { 2 - 11 } & $\begin{array}{c}\text { Pola 7- } \\
29-1\end{array}$ & 29 & $\begin{array}{c}0.0 \\
3\end{array}$ & $\begin{array}{c}100.0 \\
00\end{array}$ & 0.03 & 83 & $\begin{array}{c}0.857 \\
1\end{array}$ & $\begin{array}{c}0.931 \\
4\end{array}$ & $\begin{array}{c}0.00867630 \\
61\end{array}$ & 99.97 & $\begin{array}{c}0.354 \\
5\end{array}$ \\
\hline
\end{tabular}


Untuk menentukan arsitektur model jaringan syaraf tiruan terbaik yang akan digunakan dalam memprediksi, pada penelitian ini mengambil kriteria bahwa arsitektur terbaik adalah yang memiliki nilai rata-rata error (RMSE) terkecil, dengan penemuan goal pada epochs tercepat (terkecil nilainya) dan memiliki unjuk kerja untuk tingkat kesalahan (performance) terkecil. Kandidat terbaik untuk kriteria diatas adalah arsitektur model 7-14-1 skenario ketiga dan arsitektur model 7-29-1 skenario ketiga. Namun dengan memperbandingkan kedua arsitektur ini dan melihat nilai yang terkecil lebih banyak dimiliki suatu arsitektur untuk tiap kriterianya, maka dipilihlah arsitektur model 7-14-1 sebagai yang terbaik dengan epochs 110, RMSE 0,0033438208 dan performance 0,2185 . Solusi pengujian yang dilakukan pada penelitian ini akan digunakan untuk memprediksi jumlah ketersediaan komoditi pangan Provinsi Riau.

\section{Denormalisasi Testing Prediksi Ketersediaan Komoditi Pangan}

Proses denormalisasi adalah suatu proses untuk mengembalikan lagi data yang telah dinormalisasi kedalam bentuk data semula menggunakan nilai hasil pelatihan dan pengujian arsitektur Jaringan Syaraf Tiruan yang paling baik (Pola 7-14-1 di atas). Pada penelitian ini, denormalisasi bertujuan agar mengetahui nilai keluaran ketersediaan komoditi pangan. Agar lebih jelasnya dapat dilihat pada Tabel 5 hingga Tabel 8 berikut ini :

Tabel 5. Hasil Prediksi Luas Area Panen Provinsi Riau Untuk Tahun 2014

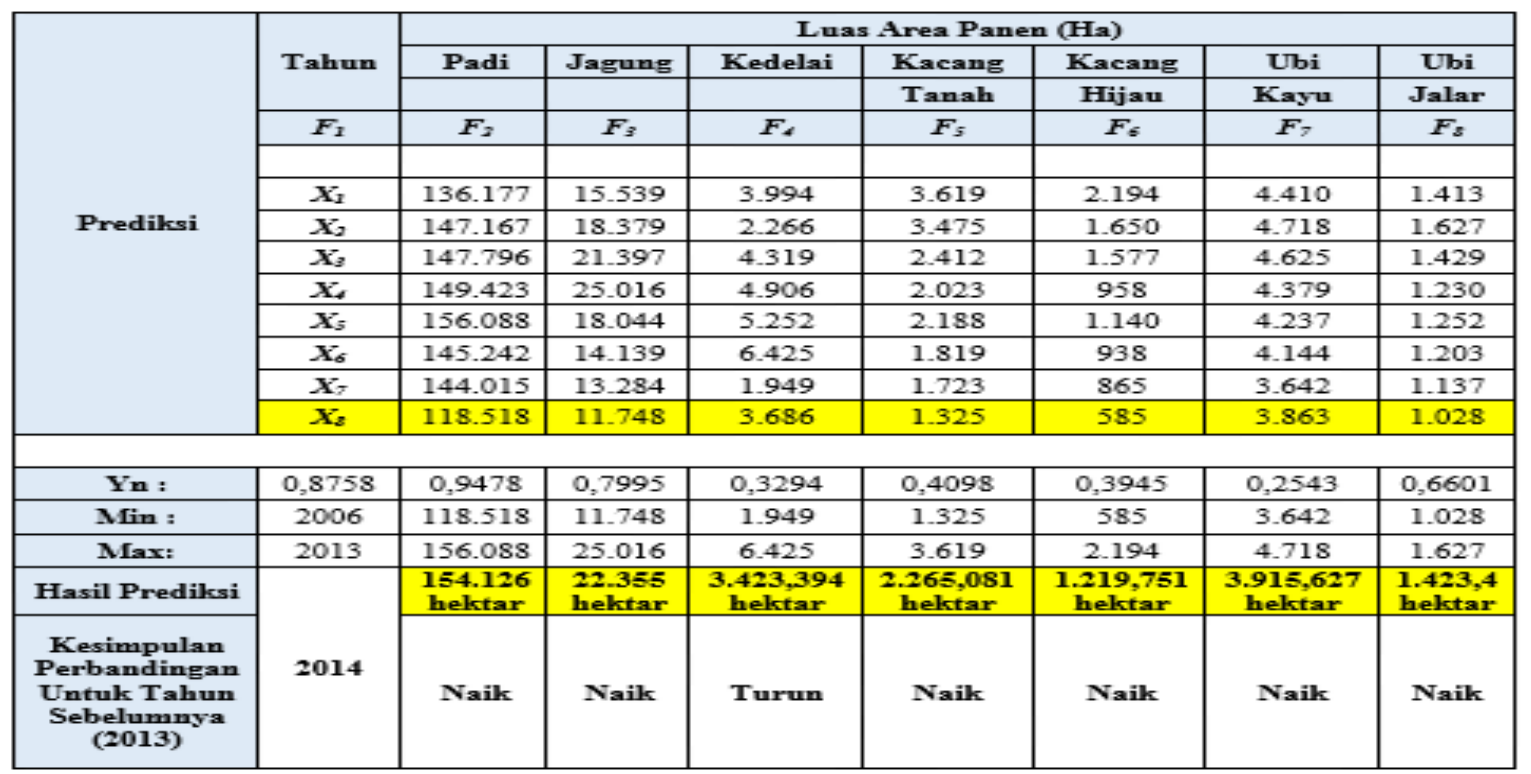

Tabel 6. Hasil Prediksi Produktivitas Komoditi Pangan Provinsi Riau Untuk Tahun 2014 
RABIT : Jurnal Teknologi dan Sistem Informasi Univrab

Volume 2 No. 2 | Juli 2017 : 83-98

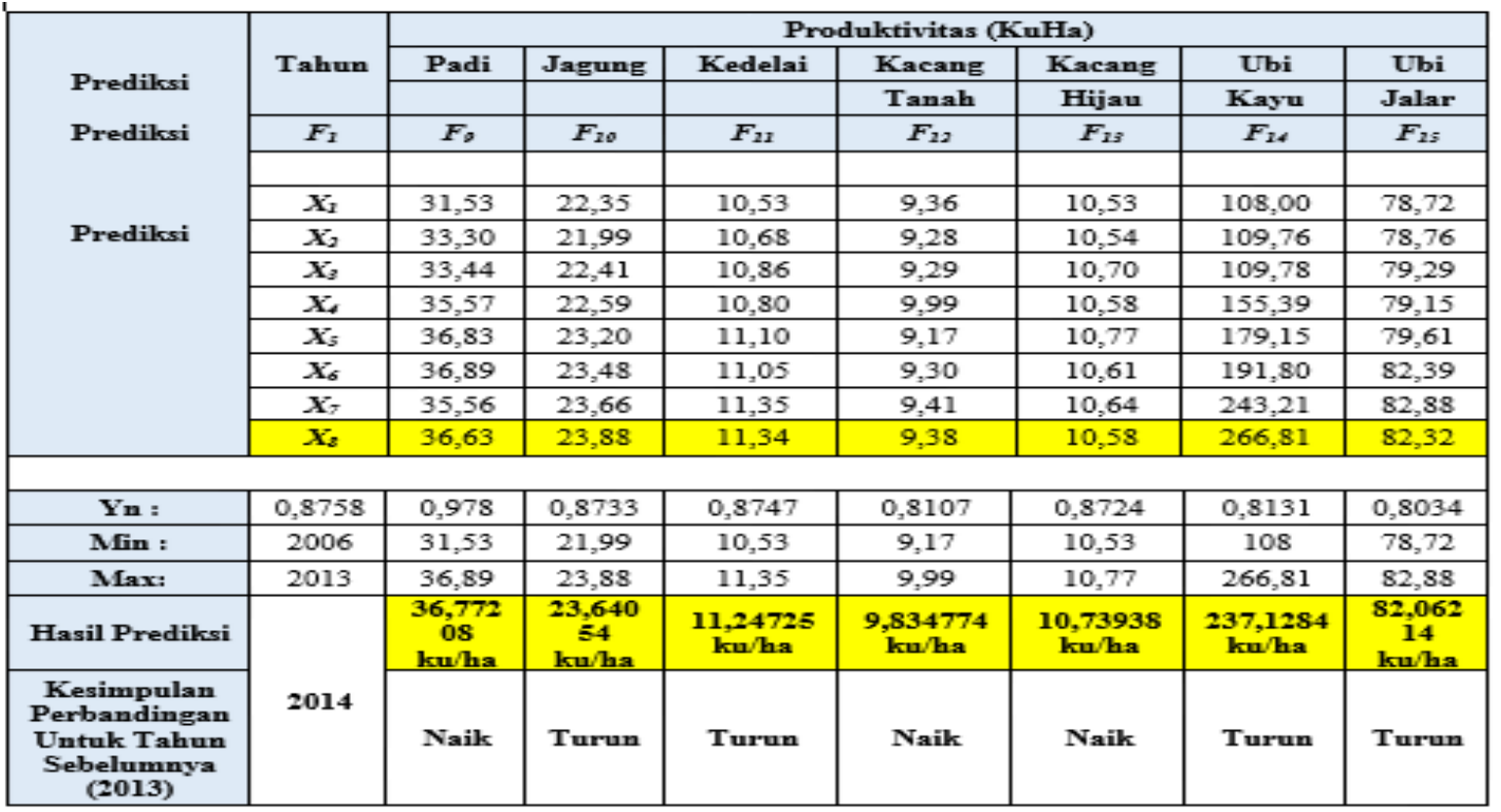

Tabel 7. Hasil Prediksi Jumlah Produksi Komoditi Pangan Provinsi Riau Untuk Tahun 2014

\begin{tabular}{|c|c|c|c|c|c|c|c|c|}
\hline & & & & & oduksi ( $\mathrm{T}_{\mathrm{C}}$ & & & \\
\hline & Tahun & Padi & Jagung & Kedelai & Kacang & Kacang & Ubi & Ubi \\
\hline & & & & & Tanah & Hijau & Kayu & Jalar \\
\hline & $F_{1}$ & $F_{16}$ & $F_{17}$ & $F_{12}$ & $F_{19}$ & $F_{20}$ & $F_{21}$ & $F_{22}$ \\
\hline & $X_{1}$ & 429,380 & 34,728 & 4,205 & 3,387 & 2,311 & 47,586 & 11,123 \\
\hline Prediksi & $X_{2}$ & 490,087 & 40,410 & 2,419 & 3,225 & 1,739 & 51,784 & 12,814 \\
\hline & $X_{3}$ & 494,260 & 47,959 & 4,689 & 2,240 & 1,688 & 50,772 & 11,330 \\
\hline & $x_{4}$ & 531,429 & 56,521 & 5,298 & 2,020 & 1,014 & 68,046 & 9,736 \\
\hline & $X_{5}$ & 574,864 & 41,862 & 5,830 & 2,007 & 1,228 & 75,904 & 9,967 \\
\hline & $X_{6}$ & 535,788 & 33,197 & 7,100 & 1,692 & 995 & 79,480 & 9,912 \\
\hline & $X_{\gamma}$ & 512,152 & 31,433 & 4,182 & 1,622 & 920 & 88,577 & 9,424 \\
\hline & $X_{z}$ & 434,151 & 28,052 & 2,211 & 1,243 & 619 & 103,070 & 8,462 \\
\hline Yn: & 0,8758 & 0,9421 & 0,8183 & 0,865 & 0,3948 & 0,7534 & 0,8319 & 0,6738 \\
\hline Min : & 2006 & 429,38 & 28,052 & 2,211 & 1,243 & 1,014 & 47,586 & 8,462 \\
\hline Max: & 2013 & 574,864 & 56,521 & 7,1 & 3,387 & 995 & 103,07 & 12,814 \\
\hline Hasil Prediksi & & $\begin{array}{c}566,440 \\
5 \text { ton }\end{array}$ & $\begin{array}{l}51,348 \\
18 \text { ton }\end{array}$ & $\begin{array}{c}6,439985 \\
\text { ton }\end{array}$ & $\begin{array}{c}2,089451 \\
\text { ton }\end{array}$ & $\begin{array}{c}749,8831 \\
\text { ton }\end{array}$ & $\begin{array}{c}93,74314 \\
\text { ton }\end{array}$ & $\begin{array}{l}11,394 \\
38 \text { ton }\end{array}$ \\
\hline $\begin{array}{c}\text { Kesimpulan } \\
\text { Perbandingan } \\
\text { Untuk Tahun } \\
\text { Sebelumnya } \\
\text { (2013) }\end{array}$ & 2014 & Naik & Naik & Naik & Naik & Naik & Turun & Naik \\
\hline
\end{tabular}

Tabel 8. Hasil Prediksi Jumlah Konsumsi Komoditi Pangan Provinsi Riau Untuk Tahun 2014 


\begin{tabular}{|c|c|c|c|c|c|c|c|c|}
\hline \multirow[b]{5}{*}{ Prediksi } & \multirow{3}{*}{ Tahun } & \multicolumn{7}{|c|}{ Konsumsi (Ton) } \\
\hline & & Padi & Jagung & Kedelai & Kacang & Kacang & Ubi & Ubi \\
\hline & & & & & Tanah & Hijau & Kayu & Jalar \\
\hline & $F_{1}$ & $F_{23}$ & $F_{24}$ & $F_{2 s}$ & $F_{26}$ & $F_{2 y}$ & $F_{2 z}$ & $F_{2 p}$ \\
\hline & & & & & & & & \\
\hline \multirow{8}{*}{ Prediksi } & $X_{1}$ & 546,418 & 11,175 & 42,465 & 4,718 & 4,966 & 26,820 & 9,685 \\
\hline & $X_{2}$ & 552,270 & 11,294 & 42,920 & 4,768 & 5,019 & 27,107 & 9,788 \\
\hline & $X_{3}$ & 577,028 & 12,194 & 46,287 & 5,137 & 5,396 & 29,214 & 10,533 \\
\hline & $X_{4}$ & 557,359 & 11,916 & 45,232 & 5,020 & 5,273 & 28,549 & 10,294 \\
\hline & $\boldsymbol{X}_{5}$ & 576,475 & 47,115 & 37,249 & 6,097 & 6,097 & 74,276 & 16,629 \\
\hline & $X_{6}$ & 611,763 & 52,814 & 56,335 & 6,455 & 6,455 & 78,634 & 17,604 \\
\hline & $\boldsymbol{X}_{\gamma}$ & 630,878 & 58,512 & 59,701 & 6,404 & 7,532 & 78,921 & 16,629 \\
\hline & $X_{z}$ & 655,637 & 59,411 & 50,663 & 6,762 & 7,225 & 82,991 & 18,109 \\
\hline & & & & & & & & \\
\hline Yn: & 0,8758 & 0,7247 & 0,824 & 0,9285 & 0,8194 & 0,782 & 0,8522 & 0,8557 \\
\hline Min : & 2006 & 546,418 & 11,175 & 37,249 & 4,718 & 4,966 & 26,820 & 9,685 \\
\hline Max: & 2013 & 655,637 & 59,411 & 59,701 & 6,762 & 7,532 & 82,991 & 18,109 \\
\hline Hasil Prediksi & & $\begin{array}{c}625,569 \\
\text { ton }\end{array}$ & $\begin{array}{c}50,922 \\
\text { ton }\end{array}$ & $\begin{array}{c}58,096 \\
\text { ton }\end{array}$ & $\begin{array}{c}6,393 \\
\text { ton }\end{array}$ & $\begin{array}{c}6,973 \\
\text { ton }\end{array}$ & $\begin{array}{c}74,689 \\
\text { ton }\end{array}$ & $\begin{array}{c}16,893 \\
\text { ton }\end{array}$ \\
\hline $\begin{array}{c}\text { Kesimpulan } \\
\text { Perbandingan } \\
\text { Untuk Tahun } \\
\text { Sebelumnya } \\
\text { (2013) } \\
\end{array}$ & 2014 & Turun & Turun & Naik & Turun & Turun & Turun & Turun \\
\hline
\end{tabular}

\section{KESIMPULAN}

Setelah melalui tahap pengujian untuk arsitektur jaringan syaraf tiruan menggunakan algoritma backpropagation dalam memprediksi ketersediaan komoditi pangan Provinsi Riau, maka didapatkan kesimpulan bahwa :

1. Algoritma backpropagation dapat melakukan proses prediksi, akan tetapi baik atau tidaknya nilai yang dihasilkan sangat dipengaruhi oleh penentuan parameter seperti besarnya learning rate dan jumlah neuron pada hidden layer.

2. Terdapat faktor-faktor yang mempengaruhi tingkat kebenaran prediksi pada jaringan syaraf tiruan backpropagation yaitu learning rate, target error, jumlah data pembelajaran dan nilai bobot yang diberikan secara acak yang pada tiap-tiap neuron.
3. Penurunan learning rate akan membuat proses pembelajaran semakin lambat.

4. Berdasarkan hasil pelatihan dan pengujian jaringan syaraf tiruan, model arsitektur yang memiliki nilai $R M S E$ paling kecil adalah arsitektur 7-14-1 dengan nilai error RMSE 0,0033438208, persentase akurasi sebesar 99,99\% dan performa 0,2185. Solusi pengujian yang dilakukan pada penelitian ini bertujuan untuk memberikan prediksi jumlah ketersediaan komoditi pangan Provinsi Riau, sehingga dapat memberikan solusi bagi Dinas Tanaman Pangan dan Hortikultura Provinsi Riau dalam mengambil kebijakan untuk menyediakan komodi pangan untuk satu tahun mendatang. 


\section{DAFTAR PUSTAKA}

[1]. Abd Alkader, Shahlla. A., Al-Allaf, Omaima. N. A. (2011).

"Backpropagation Neural Network Algorithm for Forecasting Soil Temperatures Considering Many Aspects: A Comparison of Different Approaches". The 5th International Conference on Information Technology.

[2]. Andrijasa, M. F., dan Mistianingsih. (2010). "Penerapan Jaringan Syaraf Tiruan Untuk Memprediksi Jumlah Pengangguran di Provinsi Kalimantan Timur Dengan Menggunakan Algoritma Pembelajaran Backpropagation". Jurnal Informatika Mulawarman. Vol. 5. No. 1.

[3]. Anike, Marleni., Suyoto, dan Ernawati. (2012). "Pengembangan Jaringan Syaraf Tiruan dalam Memprediksi Jumlah Dokter Keluarga Menggunakan Backpropagation (Studi Kasus : Regional X Cabang Palu)". Seminar Nasional Teknologi Informasi dan Komunikasi (SENTIKA).

[4]. Anwar, Badrul. (2011). "Penerapan Algoritma Jaringan Syaraf Tiruan Backpropagation dalam Memprediksi Tingkat Suku Bunga Bank". Jurnal SAINTIKOM. Vol. 10. No. 2.

[5]. Balaji, S. Arun. dan Baskaran, K. (2013). "Design and Development of Artificial Neural Networking (ANN) System Using Sigmoid Activation Function to Predict Annual Rice Production in Tamilnadu”. International Journal of Computer
Science, Engineering and Information Technology (IJCSEIT). Vol. 3. No.1.

[6]. Dahria, Muhammad. (2008). "Kecerdasan Buatan (Artificial Intelligence)". Jurnal SAINTIKOM. Vol. 5. No. 2.

[7]. Desiani, Anita dan Arhami, Muhammad. (2006). "Konsep Kecerdasan Buatan”. Yogyakarta : Penerbit Andi. 161-183.

[8]. Devi, C. J., Reddy, B. S. P., Kumar, K.V., Reddy, B. M., Nayak, N.R. (2012). "ANN Approach for Weather Prediction using Back Propagation”. International Journal of Engineering Trends and Technology. Vol. 3. Issue 1.

[9]. Hermawan, Arif. (2006). "Jaringan Syaraf Tiruan : Teori dan Aplikasi”. Yogyakarta : Penerbit Andi. 49-56.

[10]. Jumarwanto, Arif. (2009). "Aplikasi Jaringan Syaraf Tiruan Backpropagation untuk Memprediksi Penyakit THT di Rumah Sakit Mardi Rahayu Kudus". Jurnal Teknik Elektro. Vol. 1. No. 1.

[11]. Kusumadewi, Sri. (2010). "NeuroFuzzy : Integrasi Sistem Fuzzy dan Jaringan Syaraf”. Yogyakarta : Graha Ilmu. 69-146.

[12]. Kusumadewi, Sri. (2003). “Artificial Intelligence : Teknik dan Aplikasinya". Yogyakarta : Penerbit Andi. 203-274.

[13]. Nasution, Helfi. (2012). "Implementasi Logika Fuzzy pada Sistem Kecerdasan Buatan”. Jurnal ELKHA. Vol .4. No 2.

[14]. Prahesti, Inggit. (2013). "Implementasi Jaringan Syaraf Tiruan Algoritma Backpropagation 
untuk Memprediksi Curah Hujan di Yogyakarta”. Naskah Publikasi STMIK-AMIKOM Yogyakarta.

[15]. Puspitaningrum, Diyah. (2006). "Pengantar Jaringan Syaraf Tiruan". Yogyakarta : Penerbit Andi. 125-138.

[16]. Rebello, S., Maheshwari, U., Safreena, Souza, R. V. D. (2011). "Backpropagation Neural Network Method for Predicting Lac Gene Structures in Streptococcus Pyogenes M Group A Streptococcus Strains". International Journal for Biotechnology and Molecular Biology Research. Vol. 2 (4), PP. 6172.

[17]. Sangadji, BM. Iriansyah. (2009). "Prediksi Perilaku Pola Pengunjung Terhadap Transaksi pada Toko Buku Gramedia Menggunakan Jaringan Syaraf Tiruan Metode Backpropagation”. Jurnal Informatika. Vol. 5. No. 2. 135-150.

[18]. Siang, J.J. (2009). "Jaringan Syraf Tiruan \& Pemrogramannya Menggunakan Matlab". Yogyakarta : Penerbit Andi. 97-123.

[19]. Suyanto. (2007). "Articial Intelligence”. Bandung : Penerbit Informatika. 163-205.

[20]. Sya'diyah, Zumrotus. (2011). "Peramalan Jumlah Kendaraan Bermotor di DKI Jakarta dengan Jaringan Backpropagation”. Fakultas Keguruan dan Ilmu Pendidikan. Universitas Darussalam. Ambon.

[21]. Vamsidhar, Enireddy., Varma, K. V. S. R. P., Rao, P. Sankara., Satapati, R. (2010). "Prediction of Rainfall Using Backpropagation Neural Network Model". International Journal on
Computer Science and Engineering (IJCSE). Vol. 02. No. 04. 1119-1121.

[22]. Yanti, Novi. (2011). "Penerapan Metode Neural Network dengan Struktur Backpropagation untuk Prediksi Stok Obat di Apotek". Seminar Nasional Aplikasi Teknologi Informasi. 